\section{Impact of the Winding Angle of the Auger Blade on the Loading Process With Milling Auger Drums}

\author{
Tomasz Wydro \\ AGH University of Science and Technology, Poland
}

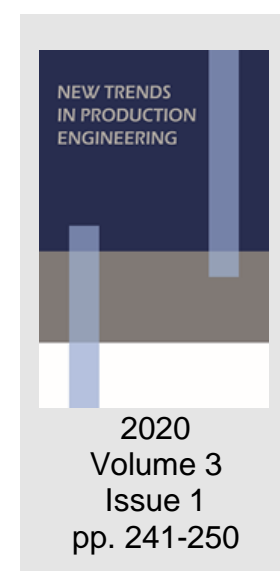

Date of submission to the Editor: 02/2020

Date of acceptance by the Editor: 03/2020

\title{
INTRODUCTION
}

Longwall shearers are the main coal mining machines in Poland. The implementation of mining with these machines is carried out by means of milling auger cutting drums, which are installed on the arms of the shearer. The milling auger cutting drums have the task of simultaneously carrying out two processes, mining and loading of separated spoil from undisturbed soil. A number of studies and experience on the construction of cutting drums have allowed for progress in the modernization of cutting drums, especially in the construction of milling auger cutting drums. The construction of the drums in question has evolved in the direction of increasing their functionality from only cutting drums to drums performing two processes simultaneously, milling and spoil loading.

The loading process is often referred to as an auxiliary process, as the milling process is considered to be the dominant process throughout the work of the drum. Loading of spoil with milling auger drums is carried out thanks to the specific structure of auger drums. This process consists of several phases: taking spoil, moving it horizontally and vertically, and pouring onto a scraper conveyor. The spoil that is not immediately loaded and remains on the floor is loaded (scraped out) onto the scraper conveyor by forcing its movement with drum blades, this process is pulsating (not continuous) and the frequency of forcing correlates with the number of blades $i$ and the rotational speed of the drum $n$.

The characteristic features of cutting drums include: kinematic or geometric parameters that have been described in the literature (Krauze 2000, Wydro \& Krauze 2011, Bołoz \& Midor 2019). Hence, drums of various sizes and shapes adapted to the kinematic parameters of the mining machine and mining and geological conditions can be found (Fig. 1).

One of the geometrical parameters affecting the quality of loading with the milling auger drum is the winding angle of the auger blade.

The drums, regardless of the method of manufacture (welded or cast), are made of a hub 1 , inside of which there is a detachable connection, i.e. a sleeve with 
an internal square4or in earlier solutions a toothed sleeve transmitting torque from the shaft on which it is mounted. On the surface of the hub 1 blades 3 are arranged, forming a cylindrical outline of the drum, to which the cutting knife holders 2 are welded. The hub is most often equipped with a cutting disc 5 , which is formed by a circular plate of a certain width and diameter. There may also be spraying nozzles 6 on the cylindrical part of the blade, which significantly reduce dust, extinguish the spark formed at the contact of the knife blade and undisturbed soil, and increase the durability of cutting tools. On the side of blades there are also fastened sheets protecting the handle against damage 7 (Błąd! Nie można odnaleźć źródła odwołania.). The cutting drum, like any construction, has appropriate parameters. In publication (Bołoz Ł., Leonel F. Castañeda 2018), the author divided the drum parameters into three groups: geometrical parameters, kinematic parameters and energy parameters.

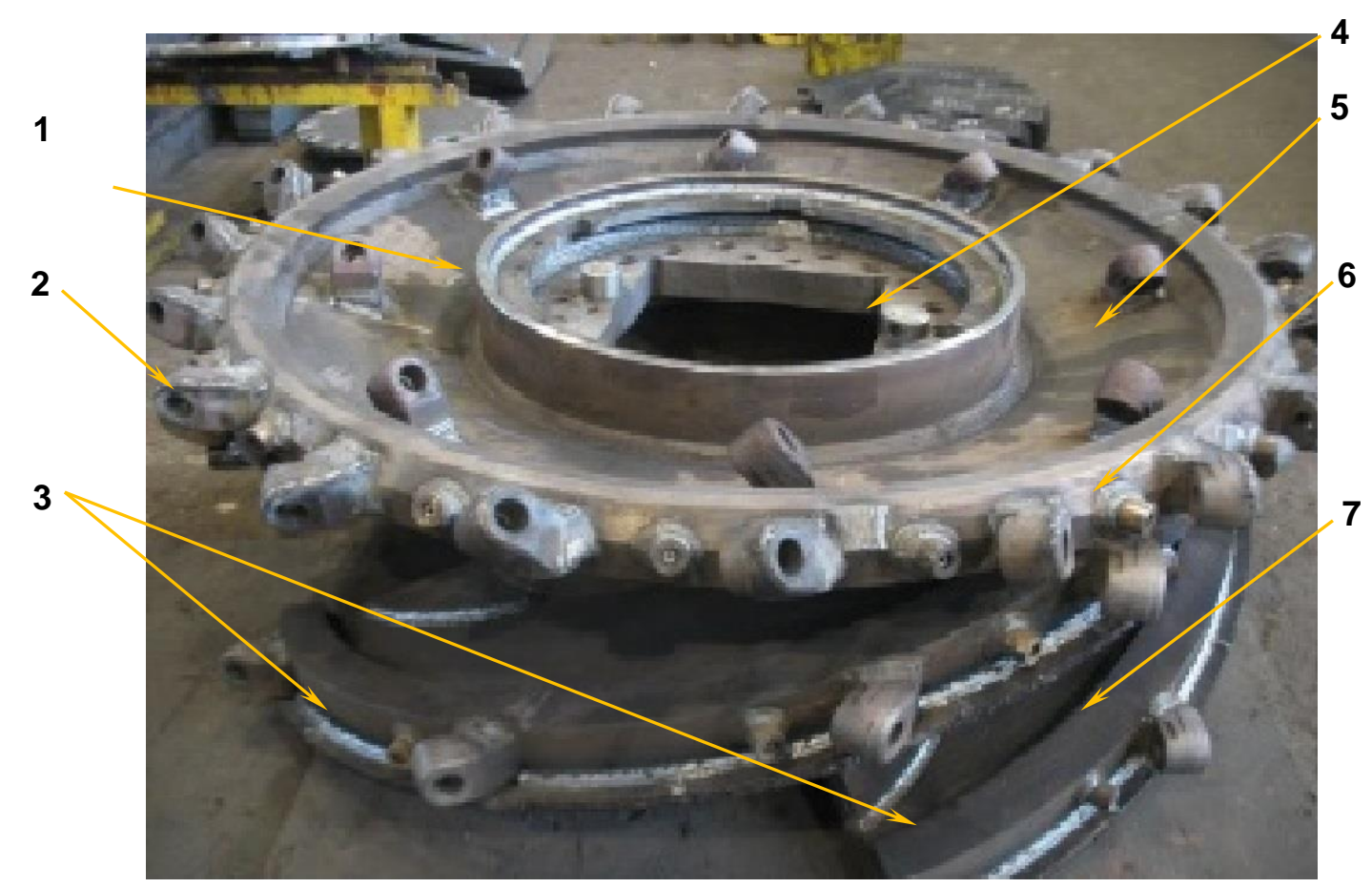

Fig. 1 Milling auger cutting drum

The above-mentioned parameters have a significant impact on both the cutting and loading processes, and therefore must meet certain criteria. Such requirements include obtaining the assumed efficiency, loading efficiency, durability and reliability as well as granulation of spoil and load variability.

\section{IMPACT OF THE WINDING ANGLE OF THE AUGER BLADE ON THE LOADING PROCESS}

One of the design parameters of milling cutting drums that affect the loading process is the winding angle of the auger blade $\alpha_{2}$.The auger blade is called a sheet with most often rectangular cross-section, specially formed and wound on the hub (Fig. 1). The auger blade, so-called auger, is on one side limited by a cutting disc, and on the other side it has an open surface, because from 
this side the spoil is transported to a longwall conveyor. Depending on the drum diameter, two to four auger blades can be installed on the hub. The blades are permanently attached (welded) to the cutting disc radially, forming a cylindrical outline of the cutting drum. The cutting drum without attached knife holders and cutting tools is called a body. The winding angle of the auger blade $\alpha_{2}$ according to (Krauze 2000) is usually assumed to be in the range of $19^{\circ}$ to $23^{\circ}$ due to the correct course of the loading process. The distance between the blades forms the so-called internal volume of the auger drum. The volume has a significant impact on the amount of spoil that the drum can transport (discharge) to the longwall conveyor, and the condition for the proper course of the loading process with the milling auger drum is the requirement that the internal volume of the drum $V_{o}$ was greater than the volume of spoil formed during mining $V_{u}$ (Wydro 2019). The pitch of the blades is also of great importance in the loading process, because in correlation with the rotational speed, it determines the speed of the spoil's movement. The relationship between the pitch of the blades $S$, the rotational speed of the drum $n$ and the resulting speeds are described in the publication (Krauze 2000).

In the same publication (Krauze 2000) we read that knowing such kinematic and geometrical parameters of the drum as longitudinal velocity, drum diameter, web, feed speed and rotational speed one can determine the optimal pitch of the blades. However, ultimately the pitch of the blades is determined only after taking into account the so-called angle of coverage of individual blades, which should not be less than the value of $20^{\circ}$, the number of knives in the cutting line, and should also take into account the conditions of cutting and loading (Horst 1985).
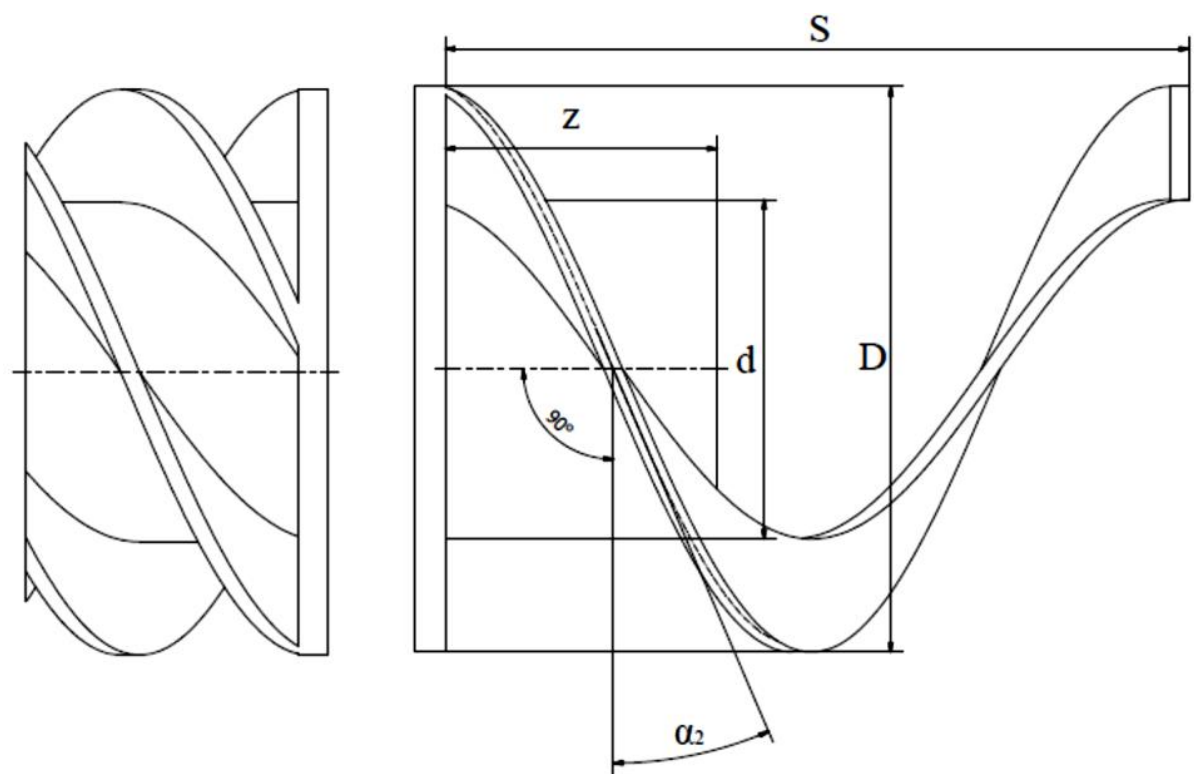

Fig. 2 Diagram of the auger drum body

D - diameter of the drum (body) without knives, $Z$ - web of the cutting-loading part, d - hub diameter, $S$ - pitch of the auger blade, $\alpha_{2}$ - winding angle of the auger blade

In order to increase the efficiency of the loading process, it is also possible to shape the auger blades so that the longitudinal velocity of the spoil increases 
towards the conveyor, an example of which are the so-called globoid blades. Bearing in mind the increase in the efficiency of loading with auger drums at Krummenauer, the designers designed the so-called globoid drum (Krummenauer 2020). The drum structure is characterized by a steady increase in the pitch of the blade from the spoil's output side and a truncated cone hub, which results in more efficient discharge of the spoil towards the output. In order to check the advantages of this construction, the company conducted tests in one of the coal mines. The tests consisted in comparing the work of a traditional drum with a cylindrical hub and straight blades with a globoid drum (Fig. 23). The conducted tests allowed to formulate conclusions in which it was assessed that the globoid drum significantly improves loading capacity, increases the feed speed and increases the output of a thicker assortment (Krummenauer 2020).

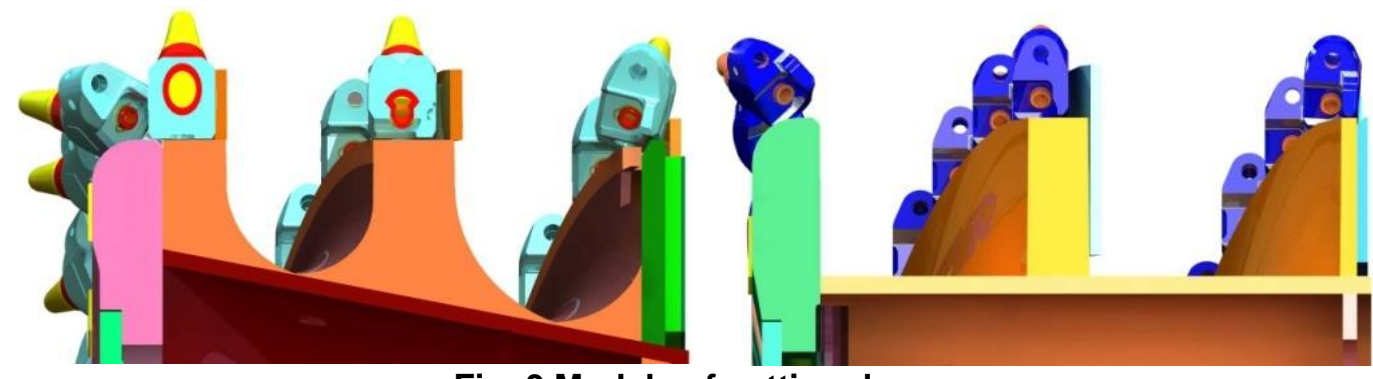

Fig. 3 Models of cutting drums

(globoid drum on the left, drum with cylindrical hub on the right)

Source: (Krummenauer 2020)

Also in the publication (Wydro 2015) the researcher on the basis of his own laboratory tests showed what effect some of the construction parameters of the cutting drum have on the loading efficiency of the milling auger drum. Five fourinput milling auger drums were used for this test (Fig. 24). These drums differed only in the angle of inclination of the auger blade $\alpha_{2}$ (winding angle of the auger blade), while the outer diameter (height of the blade) and hub diameter were constant parameters, so the ratio of the outer diameter $D$ to the hub diameter $d$ was constant. Table 1 summarizes the structural parameters of the drums used for the tests.

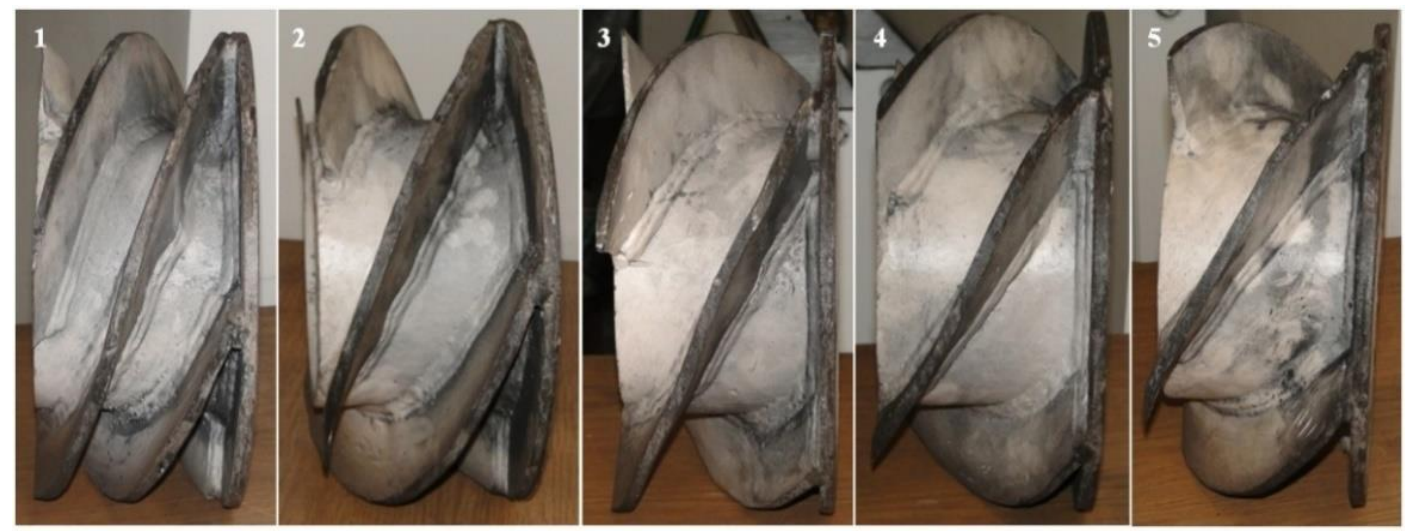

Fig. 4 Milling auger cutting drums used for laboratory tests

Source: (Wydro 2015) 
Table 1 Construction parameters of drums used for tests

\begin{tabular}{|c|c|c|c|c|c|c|c|}
\hline Item & $\begin{array}{c}\text { Web } \\
\text { without } \\
\text { cutting } \\
\mathbf{d i s c} \\
\mathbf{Z}[\mathbf{m}]\end{array}$ & $\begin{array}{c}\text { Diameter } \\
\text { of drum } \\
\mathbf{D}[\mathrm{m}]\end{array}$ & $\begin{array}{c}\text { Diameter } \\
\text { of hub } \\
\mathbf{d}[\mathbf{m}]\end{array}$ & $\begin{array}{c}\text { Blade } \\
\text { thickness } \\
\mathbf{b}[\mathrm{m}]\end{array}$ & $\begin{array}{c}\text { Number } \\
\text { of } \\
\text { blades }\end{array}$ & $\begin{array}{c}\text { Blade } \\
\text { Winding } \\
\text { angle } \\
\mathbf{a}_{2}\left[^{\circ}\right]\end{array}$ & $\begin{array}{c}\text { Drum } \\
\text { internal } \\
\text { volume } \\
\mathbf{V}_{\mathbf{o}}\left[\mathbf{m}^{3}\right]\end{array}$ \\
\hline 1 & 0.133 & 0.334 & 0.2 & 0.012 & 4 & 15.35 & 0.00618 \\
\hline 2 & 0.133 & 0.334 & 0.2 & 0.012 & 4 & 18.29 & 0.00639 \\
\hline 3 & 0.133 & 0.334 & 0.2 & 0.012 & 4 & 19.81 & 0.00647 \\
\hline 4 & 0.133 & 0.334 & 0.2 & 0.012 & 4 & 24.66 & 0.00666 \\
\hline 5 & 0.133 & 0.334 & 0.2 & 0.012 & 4 & 26.20 & 0.00670 \\
\hline
\end{tabular}

Based on the tests carried out which were described in the publication (Wydro 2015), conclusions have been drawn which show that the highest loading efficiency $\eta_{*}$ with drums with different winding angle of auger blade $\alpha_{2}$ was obtained by drums with the lowest winding angle $\alpha_{2}$ for grain size in the range from 0 to $10 \mathrm{~mm}$ regardless of kinematic parameters: feed speed $v_{p}$ and drum rotation speed $n$, while for grain size in the range of $20 \mathrm{~mm}$ to $45 \mathrm{~mm}$ the drum with the largest winding angle $\alpha_{2}$ achieved the highest efficiency. Such test results may suggest that the different grain size of the spoil is affected by the winding angle of the auger blade.

In connection with the above, it can be presumed that in order to obtain a thicker assortment one would have to use drums with a larger winding angle of the auger blade $\alpha_{2}$, of course, taking into account the knife system.

The design of the milling auger drums is very original and unique in the industry outside the mining industry. Although cutting drums are the main cutting elements (assemblies) of many machines such as milling machines working in the rock industry, road and floor milling machines. Milling drums are designed for mining various types of natural and artificial mineral resources. They differ in construction, kinematic and energy parameters, and these differences result from the place of their application, i.e. the type of material being mined. As mentioned earlier, the loading process with milling auger drums is carried out using blades, while in the case of other machines equipped with cutting drums, the loading process is carried out by means of an appropriately shaped drum body, where the loading elements (rings, covers) are set so as to form a helix (auger). Then the rotation of the drum causes the spoil to move along its axis to the collection site (conveyor, feeder) (Krauze et al 2009). Of course, in the case of such machines as road headers, floor milling machines or road milling machines, there is no question in its geometry of the winding angle of the auger blade, nevertheless the knife system is designed so that the knife holders also have the function of loading. Knives with handle covers are arranged along, a helix wound so that the spoil was moved to the combine's (arm) axis. An example of such solutions are the mining drums of a road header and road milling machine presented in Figure 4 below.

The knife system designed in this way (arrangement of holders with cutting tools) ensures not only the correct milling process, but also the removal of spoil (loading). 
Structural parameters have particular importance for the process of milling and loading with milling auger drums during mining in low walls. The use of longwall shearers equipped with milling auger drums in low walls is a problem precisely because of the loading process onto, a longwall conveyor.

Insufficient space (loading door) under the road header arm causes it to remain on the road header path (Krauze et al 2010). Leaving spoil on the road header path may cause the conveyor to be raised, consisting in lifting it on the spoil left behind. This can cause difficulties in maintaining the road header work at the height assumed for a given wall. In addition, this can lead to reduced durability of road header knives (cutting drums cut into the floor rocks), increase in work dynamics and increase in dustiness (Szlęzak \& Szlęzak 2013, Wydro 2019). Hence, a significant problem for road headers guided after the conveyor and those extended beyond the conveyor is to cover part of the drum by both the boom and the conveyor.

One of the companies specializing in the production of road headers for ultrathin seams below $1 \mathrm{~m}$ is Mackina-Westfalia S.A., that's why it's worth mentioning one of the company's designs, the HMG100-TP road header (Fig. 5) (Bołoz, 2018).
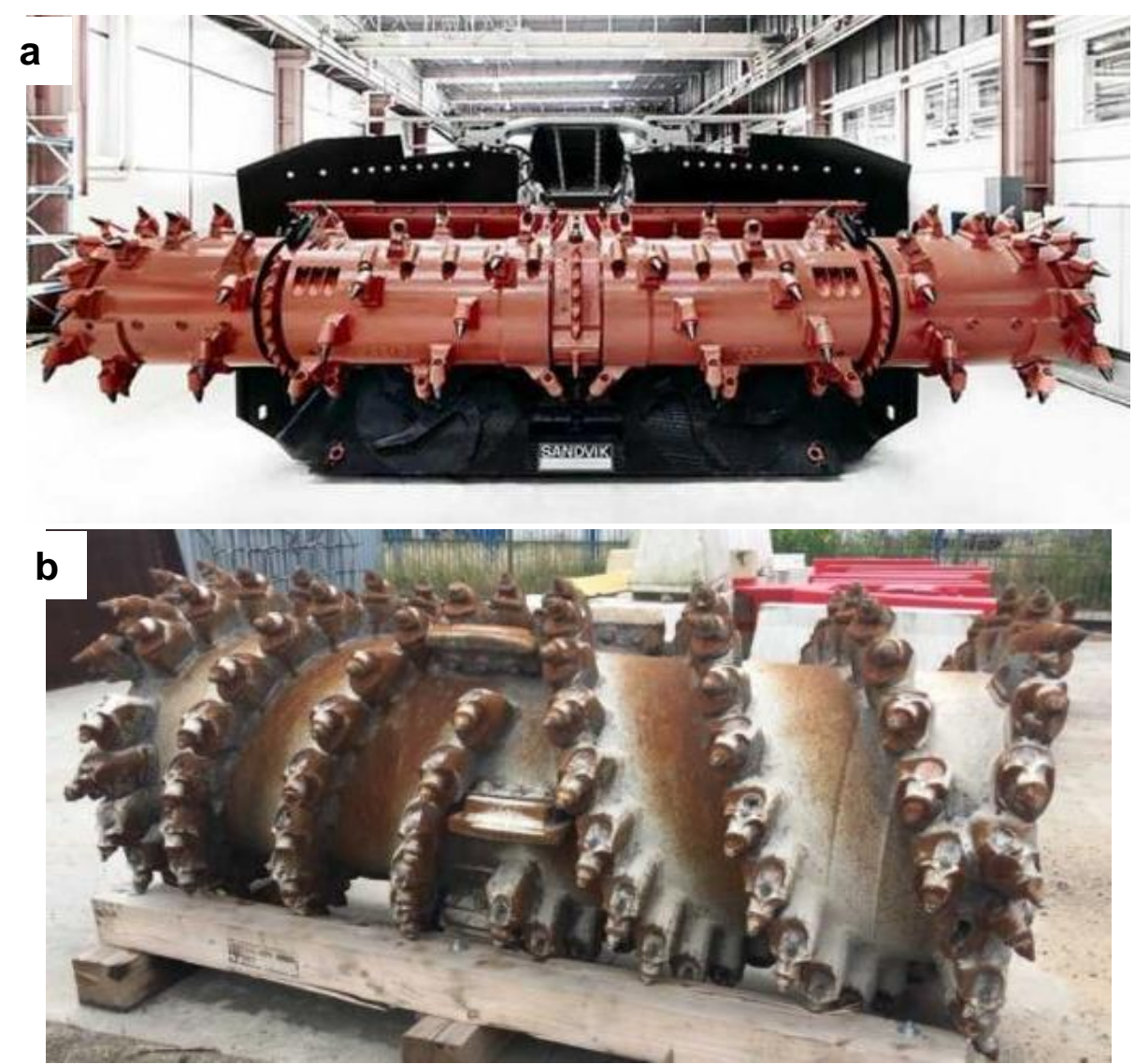

Fig. 5 Cutting drums (a. on the left a Sandvik road header, b. on the right a Wirtgen road milling cutter)

It is a single-drum, single-boom shearer with a tensionless feed system, where the range of used drums is in the range of 0.44-0.90 (Bołoz 2018, Bołoz \& Castañeda). The size of the used cutting drum diameters may raise the question 
of how the spoil is discharged to a longwall conveyor, where the height of the blades is not great, and thus the volume of the drum. Looking at the pictures (Fig. 6 and Fig. 7) it can be concluded that the pitch of the blades is large enough to create the appropriate space (internal volume of the drum) between the blades and the spoil could be discharged onto a longwall conveyor.

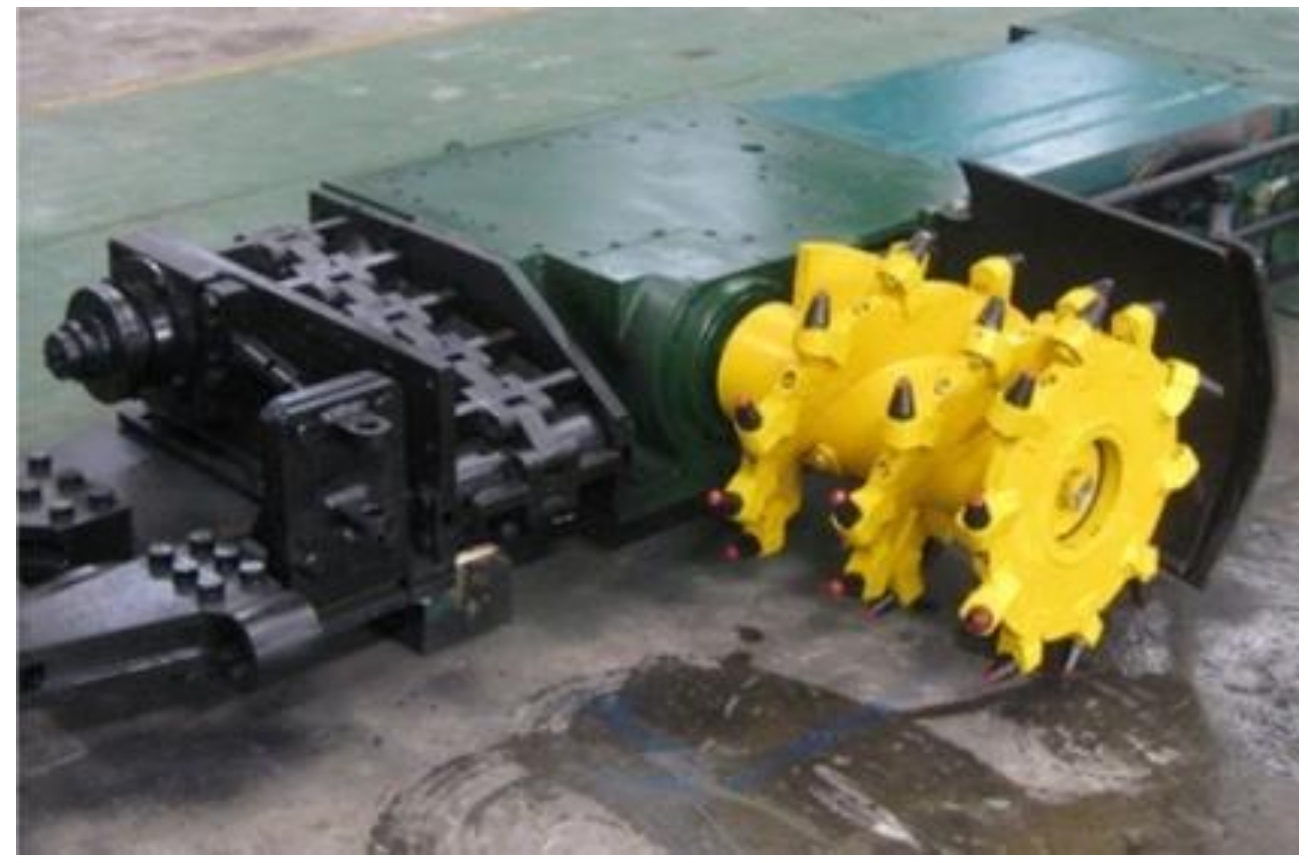

Fig. 6 Single-drum HMG100-TP road header for ultra-thin seams

Source: (Bołoz 2018)

by Mackina-Westfalia S.A.

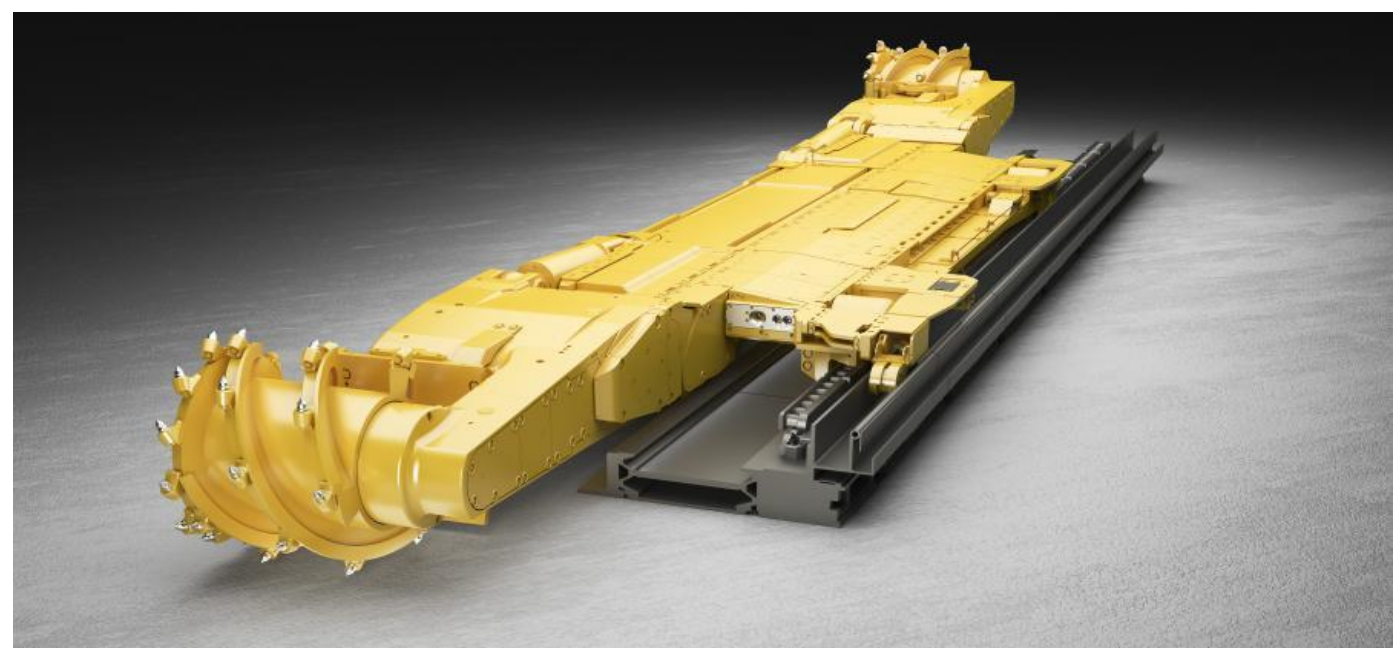

Source: (Eickoff 2020)

Fig. 7 Shearer loader by Eickhoff

From a technical point of view, the inclination of the excavation (seam drop angle) is undoubtedly one of the difficulties, and such conditions include transverse and longitudinal slope of longwalls. In mining practice, in the case of inclined seams, it is desired to orient the excavation such that the transverse angle of the longwall is as small as possible, allowing higher values of the longitudinal angle of up to $45^{\circ}$. This is mainly due to the operational capabilities 
of machinery and equipment working in the longwall (Krauze 1994, Krauze et al 2009).

Particular attention should be paid to mining after drop when there is a transverse slope in the longwall. Measurements carried out in mines in such inclined walls allowed to formulate the conclusions that with transverse inclination of the wall over $15^{\circ}$ in the direction of removal, the mining efficiency is reduced to $60 \%$ when mining with a cutting drum with a diameter of $1600 \mathrm{~mm}$, and up to $80 \%$ with a cutting drum with a diameter of $2000 \mathrm{~mm}$ (Krauze 2000). In such mining and geological conditions, the loading process can be improved by tilting the blades in the direction of discharging the spoil.

Another way to improve the loading efficiency is to use the construction of the cutting drum with blades curved towards the body, with the inclination of the blade increasing in the direction of the spoil discharge as the drum radius increases (Fig. 7). It is also possible to use the conical shape of the drum shell, with the blades positioned perpendicular to the cone of the drum shell.

\section{SUMMARY}

Cutting drums are widely used in many machines in which they are the main cutters. They are used in longwall shearers mining coal, in milling machines working in the rock industry and road milling machines. Although these processes in all of these drums are analogous, they differ in structural, kinematic and energy parameters, and these differences result from their place of application, i.e. the type of material being treated. They owe a wide range of application mainly to the possibility of carrying out two processes simultaneously, i.e. cutting and loading.

References to analysis and research on the loading process can be found more frequently in the literature. Bearing the above in mind, the publication presents selected parameters affecting the loading process with milling auger drums. An attempt was made to analyse the loading process in terms of the design parameter, which is the winding angle of the auger blade and its pitch. The analysis was done and attention was paid to the possibility of introducing structural changes for some mining and geological conditions in a given excavation.

It should be added that mining and geological conditions have a great impact on the loading process, especially the transverse and longitudinal slope of the longwall and its height. It is important to treat the selection of cutting drums for each longwall individually. Such approach to designing will later allow to avoid any downtime of the mining machine, increase the unexpected dynamics and variability of the load caused by their work (Wydro 2015, Krauze 2009, Krauze 1994 Bołoz \& Castañeda, 2018, Bołoz \& Midor 2018).

Attention should be paid to the conditions of correct operation of the milling auger drum in order to obtain the assumed parameters of the particle size distribution of the spoil and the associated dust during drum operation. It is also important to meet the conditions of the loading process presented in the article, 
which directly affect the quality of both processes - mining and loading, and, consequently, daily production.

\section{REFERENCES}

Bołoz $\nvdash$.: Longwall shearers for exploiting thin coal seams as well as thin and highly inclined coal seams, "Mining - Informatics, Automation and Electrical Engineering" 2018, 2: 59-65,.

Bołoz Ł., Leonel F. Castañeda (2018). Computer-aided support for the rapid creation of parametric models of milling units for longwall shearers, Management Systems in Production Engineering, 26(4), pp. 193-199.

Bołoz Ł., Midor K. (2018). Process innovations in mining industry and effects of their implementation presented on example of longwall milling heads, Acta Montanistica Slovaca, 23(3), pp. 282-292.

Bołoz Ł., Midor K. (2019). Procedure of choosing an optimal offer for a conical pick as an element of realizing the sustainable development concept in a mining enterprises, Acta Montanistica Slovaca, 24(2), pp. 140-150,

Horst H.D.: Optimierung von Schneidwalzen fur Geinungsmaschinen. referat na Konferencje w Miskolcu, 1985

Krauze K.: Urabianie skał kombajnami ścianowym, Katowice, Wydawnictwo Śląsk, 2000.

Krauze K.: Wpływ wybranych parametrów konstrukcyjnych frezujących organów ślimakowych na obciążenie ścianowego kombajnu węglowego. Wydawnictwo AGH, seria Rozprawy i monografie, Kraków 1994.

Krauze K., Wydro T., Bołoz Ł.: Frezujące organy maszyn urabiających. Przegląd Górniczy 2009, nr. 7-8.

Krauze K., Wydro T., Bołoz Ł.: Problemy związane z procesem ładowania frezującymi organami ślimakowymi. W: Problemy bezpieczeństwa w budowie i eksploatacji maszyn i urządzeń górnictwa podziemnego, Red. Krauze K., Lędziny 2010,

Szlązak N., Szlązak J.: Wentylacja wyrobisk ścianowych w kopalniach węgla kamiennego, w warunkach zagrożeń metanowego i pożarowego, „Górnictwo i Geologia" 2013, 8, 2: 115-131.

Wydro T.: Influence of the plow filling and thread angle on to the plow head efficiency - Wpływ współczynnika wypełnienia organu oraz kąta nawinięcia płata ślimaka na sprawność ładowania frezującymi organami ślimakowymi Archives of Mining Sciences; ISSN 0860-7001. 2015 vol. 60 no. 1, pp. 143-156. Bibliogr. p. 156

Wydro T. K Krauze,: „Analiza procesu ładowania frezującymi organami ślimakowymi na podstawie badań laboratoryjnych", Monografia, Akademia Górniczo-Hutnicza im. Stanisława Staszica w Krakowie. ISBN 83-915742-9-6. Na okł. dod.: TUR 2011.

Krummenauer: https://anlagenbau.krummenauer.de/node/158, Luty 2020

Sandvik: https://www.miningglobal.com/machinery/sandvik-advances-further-longwallmining-introduces-new-mb670-1-bolter-miner, Luty 2020

Wirtgen: https://imged.pl/beben-do-frezarki-wirtgen-w2000-32493712.htmlLuty 2020 


\section{Abstract.}

This publication addresses the impact of selected design parameters of milling auger cutting drums on the loading process, and above all the winding angle of the auger blade. The loading process is often referred to as an auxiliary process because the milling process is considered to be the dominant throughout the work of the cutting drum. The correct determination of the relationship between the mining process and the loading process allows to understand how the individual design and kinematic parameters of the mining drums and the mining machine on which they are installed affect each other. The publication discusses the problem of loading with milling cutting drums and ways to increase its efficiency. The research results of the loading process have been presented, affecting the efficiency of this process in the aspect of various angles of inclination of the auger blades. Based on the tests, conclusions have been formulated that allow for the possible selection of an appropriate winding angle for the auger blade, depending on the granulation of spoil.

Keywords: longwall shearer, spoil loading, cutting drums, laboratory tests 